\title{
Effects of light and food availability on toxin production, growth and photosynthesis in Dinophysis acuminata
}

\author{
Lasse Tor Nielsen $^{1, *}$, Bernd Krock ${ }^{2}$, Per Juel Hansen ${ }^{1}$ \\ ${ }^{1}$ Marine Biological Section, University of Copenhagen, Strandpromenaden 5, Helsingør 3000, Denmark \\ ${ }^{2}$ Alfred-Wegener-Institute for Polar and Marine Research, Am Handelshafen 12, Bremerhaven 27570, Germany
}

\begin{abstract}
Diarrhetic shellfish poisoning (DSP) toxins constitute a severe health risk to shellfish consumers and a serious economic risk to the shellfish industry. The most prominent producers of DSP toxins are the mixotrophic dinoflagellates Dinophysis spp., which rely on chloroplasts from their prey, the ciliate Mesodinium rubrum; i.e. they are kleptoplastidic. Studies based on field collected material have indicated that cellular toxin contents in Dinophysis spp. vary intraspecifically by several orders of magnitude, but the regulating factors of cellular toxin contents are still poorly understood. We isolated 7 strains of $D$. acuminata, all of which produced pectenotoxin-2 (PTX-2) in the range of 12.7 to $35.6 \mathrm{pg} \mathrm{cell}^{-1}$ when supplied with abundant nutrients, light and food. One strain was selected for detailed studies on the effects of irradiance and food availability on photoacclimation, photosynthesis, growth and toxin production. Photoacclimation was detected for the first time in this genus, indicating some genetic control of sequestered chloroplasts. Growth and photosynthesis increased 4 -fold with irradiances from 7 to $130 \mu \mathrm{mol}$ photons $\mathrm{m}^{-2} \mathrm{~s}^{-1}$ after a minimum of $2 \mathrm{wk}$ under ample food conditions. Despite this, cellular PTX-2 content increased only slightly from (mean $\pm \mathrm{SE}$ ) $4.6 \pm 0.3$ to $7.8 \pm 1.1 \mathrm{pg}$ PTX-2 cell ${ }^{-1}$. Toxin production continued for up to $30 \mathrm{~d}$ after food was depleted, leading to a build-up of toxin in $D$. acuminata cells to $24.7 \pm 1.7 \mathrm{pg}$ PTX-2 cell ${ }^{-1}$. Thus, we demonstrate that PTX-2 content is not directly coupled to irradiance and that PTX-2 production is not directly associated with ingestion of ciliate prey. Intraspecific variations in toxicity are instead most likely governed primarily by growth phase and genetic differences between different populations of Dinophysis spp.
\end{abstract}

KEY WORDS: Dinophysis acuminata - Diarrhetic shellfish poisoning - DSP - Mixotrophy · Pectenotoxin $\cdot$ PTX $\cdot$ Food availability $\cdot$ Light

\section{INTRODUCTION}

Diarrhetic shellfish poisoning (DSP) outbreaks have been reported frequently ever since the first documented accounts from Japan in 1976 and 1977 (Yasumoto et al. 1978). They appear more or less worldwide, with reported incidents from Asia, Australia, New Zealand, Africa, Europe and South, Central and North America (Reguera et al. 2012). Clinical symptoms include diarrhea, vomiting and abdominal pain, but human fatalities have never been linked to DSP incidents. However, DSP toxins are tumor promoting and thus constitute a severe, chronic threat to shellfish consumers (Suganuma et al. 1988).

A few years after its first discovery, DSP was linked to the dinoflagellate Dinophysis fortii (Yasumoto et al. 1980), and several species of Dinophysis have now been shown to contain DSP toxins (Reguera et al. 2012). Some benthic species of Prorocentrum, another dinoflagellate genus, are also capable of producing DSP toxins, but Dinophysis spp. are generally considered the primary causative organism of DSP 
(Murakami et al. 1982, Pan et al. 1999, Reguera et al. 2012). More than 200 species have been ascribed to the genus Dinophysis (Hallegraeff \& Lucas 1988). Ten of these, as well as 2 species of the closely related genus Phalacroma, have been unambiguously reported to contain DSP toxins, but only 7 have been linked to DSP incidents (Reguera et al. 2012).

Two groups of toxins are produced by Dinophysis: (1) okadaic acid (OA) and its derivates, the dinophysistoxins (DTXs), and (2) the pectenotoxins (PTXs) (Tong et al. 2011). The toxicity of PTXs has, however, been questioned within the last decade since they do not appear to be toxic when ingested orally (Miles et al. 2004a). Yet, PTX is still subject to a regulatory threshold of $160 \mathrm{\mu g} \mathrm{kg}^{-1}$ mussel meat and thus retains the potential to put mussel harvesting on hold (European Council 2004).

Occurrence of causative species above a certain threshold often provides the grounds for closures of mussel harvesting, but this may not be a particularly well-suited method since in situ toxin contents of Dinophysis spp. are highly intra- and interspecifically variable. For example, Dinophysis acuta varied in OA content from 0.8 to $9.5 \mathrm{pg} \mathrm{cell}^{-1}$ during $\sim 1 \mathrm{mo}$ of sampling at the same site off the coast of Western Iberia. Similarly, DTX-2 and PTX-2 varied from 1.0 to 6.6 and 0.4 to $3.1 \mathrm{pg} \mathrm{cell}^{-1}$ respectively (Pizarro et al. 2009). In another recent study from off the SW coast of Ireland, D. acuta contained up to 16, 28 and $39 \mathrm{pg}$ cell $^{-1}$ of OA, DTX-2 and PTX-2 respectively (Fux et al. 2010), and in Sweden, the same species has been found with no or very low levels of OA (Lindahl et al. 2007). Likewise, in situ populations of $D$. acuminata have also been found with highly different toxin contents. Blanco et al. (2007) found D. acuminata with high amounts of PTX-2 (180 pg cell-1) as the sole toxin, Jørgensen \& Andersen (2007) found it with varying, high amounts of OA (19 to $72 \mathrm{pg} \mathrm{cell}^{-1}$ ) and no DTX (PTXs were not measured), and Kim et al. (2010) found it with varying contents of OA (0.4 to $\left.0.9 \mathrm{pg} \mathrm{cell}^{-1}\right)$, DTX-1 (0 to $\left.0.8 \mathrm{pg} \mathrm{cell}^{-1}\right)$ and PTX-2 (0 to $18.5 \mathrm{pg} \mathrm{cell}^{-1}$ ) as did MacKenzie et al. (2005) (OA: 0.1 to $1.2 \mathrm{pg} \mathrm{cell}^{-1}$, DTX-1: 0.1 to $2.4 \mathrm{pg} \mathrm{cell}^{-1}$, PTX-2: 2.4 to $25.8 \mathrm{pg} \mathrm{cell}{ }^{-1}$ ). Additionally, cells of both $D$. acuta and D. acuminata may contain a suite of OA diol-esters and DTX and PTX isomers, often in unique combinations and/or quantities for every new sample or isolate (Vale \& Sampayo 2000, Miles et al. 2006, Fux et al. 2011).

Dinophysis species (sensu stricto) all seem to contain chloroplasts of cryptophyte origin, and it was a mystery for a long time whether these chloroplasts were fully incorporated or whether they were sequestered through ingestion of cryptophyte chloroplast-containing prey. A breakthrough came in 2006, when Park et al. succeeded in culturing $D$. acuminata using the mixotrophic ciliate Mesodinium rubrum as prey (Park et al. 2006). M. rubrum itself preys on cryptophytes within the Teleaulax/ Plagioselmis/Geminigera clade (Hansen et al. 2012). At present, 6 species are in culture worldwide $(D$. acuminata, $D$. acuta, D. caudata, $D$. infundibulus, $D$. forti and $D$. tripos). All data published so far suggest that Dinophysis species are obligate mixotrophs, relying on both light and food uptake for growth in the long term (Riisgaard \& Hansen 2009, Kim et al. 2010). Not much is known about the growth of Dinophysis species at low irradiances or to what extent food uptake can substitute photosynthesis. However, it is known that as much as $80 \%$ of the carbon uptake comes from ingestion of prey at high irradiance and high prey concentration (Riisgaard \& Hansen 2009). It is also now evident that prey uptake supplies Dinophysis cells with functional chloroplasts (Kim et al. 2012). To what extent Dinophysis species can photoacclimate is presently unknown. This raises a number of questions concerning the cellular toxin content and production, e.g. to what extent is cellular toxin content and production coupled to photosynthesis, food uptake and growth?

The first attempts to study toxin production of Dinophysis spp. revealed huge differences in cellular toxin contents, and values ranging from 0 to 59,0 to 10 and 0 to $170 \mathrm{pg} \mathrm{cell}^{-1}$ were found for OA, DTX-1 and PTX-2 respectively (Hackett et al. 2009, Kamiyama \& Suzuki 2009, Kamiyama et al. 2010, Fux et al. 2011, Nagai et al. 2011, Tong et al. 2011). Thus, toxins found in Dinophysis vary considerably in cellular quotas - all of them even to the extent that they can be completely absent. Despite recent studies, it is still largely unknown what causes these variations in toxin content among species of Dinophysis. Among the few available studies, Kamiyama et al. (2010) showed that during the exponential growth phase, temperature $\left(10\right.$ to $\left.22^{\circ} \mathrm{C}\right)$ affected cellular contents of PTX-2, whereas it had no significant effect on OA and DTX-1. Tong et al. (2011) similarly found that irradiances from 65 to $300 \mu \mathrm{mol}$ photons $\mathrm{m}^{-2} \mathrm{~s}^{-1}$ (all levels were growth saturating) did not affect cellular toxin contents or production rates (OA, DTX-1, PTX2 and OA-D8). They did find, however, that toxin production continued long into the stationary growth phase, and $D$. acuminata thus accumulated toxins intracellularly when not dividing. However, the variations in toxin contents were within 1 order of magnitude, and cellular toxin quotas of OA and DTX-1 
were in the very low end of the spectrum found for Dinophysis cultures (OA: <50 fg cell ${ }^{-1}$ and DTX-1: $<330 \mathrm{fg} \mathrm{cell}^{-1}$ ). No environmental factors have so far been found to control toxin contents of any Dinophysis species to the level that toxins appear or disappear, indicating that Dinophysis toxicity is subject first and foremost to strong genetic control.

Thus, the aim of the present study was to examine the regulating factors for toxin production in Dinophysis acuminata, a key DSP-producing harmful algal bloom species. By sampling different populations of $D$. acuminata and performing controlled laboratory experiments, we assessed genetic variability, and effects of irradiance, food availability and/or growth phase on the cellular toxin content and rate of production.

\section{MATERIALS AND METHODS}

\section{Cultures and growth conditions}

Cultures of Teleaulax amphioxeia and Mesodinium rubrum were isolated from Helsingør Harbor during summer 2009. Every 3 to 4 d, M. rubrum (MBLDK2009) was fed T. amphioxeia (K-0434, Scandinavian Culture Collection of Algae and Protozoa) at a ratio of 1:10 to enable mixotrophic growth. During 2009, 7 non-clonal (based on $\sim 10$ cells each) cultures of Dinophysis acuminata were isolated from 7 different locations in Denmark, including Limfjorden, Mariager Fjord, Lillebelt and Oresund. These were grown in 24-well multi-dish trays and fed $M$. rubrum once or twice a week at a ratio of $\sim 1: 10$. All cultures were grown in $\mathrm{f} / 2$ autoclaved seawater medium with $2.3 \pm 0.1 \mathrm{mmol} \mathrm{l}^{-1}$ dissolved inorganic carbon (DIC), a $\mathrm{pH}$ of $8.0 \pm 0.02$ and a salinity of $32 \pm 1$ (Guillard \& Ryther 1962). They were kept in a temperaturecontrolled room at $15^{\circ} \mathrm{C}$ and provided $\sim 130 \mu \mathrm{mol}$ photons $\mathrm{m}^{-2} \mathrm{~s}^{-1}$ PAR on a $16 \mathrm{~h}$ light:8 h dark cycle. Irradiance was delivered by Osram cool white 58W/ 640 fluorescent tubes. All cultures were non-axenic. All established cultures of $D$. acuminata were analyzed for DSP toxin contents using $0.5 \mathrm{ml}$ centrifugal filters as described below.

\section{Toxin sampling tests}

Initial experiments were conducted with one of the 7 Dinophysis acuminata cultures, 'FR101009' (isolated from Lillebelt, October 2009), to test the DSP toxin sampling method. D. acuminata cells were har- vested from a $200 \mathrm{ml}$ culture using Eppendorf tubes with $0.5 \mathrm{ml}$ centrifugal filter inserts (VWR) with a pore size of $0.45 \mu \mathrm{m}$. The aims were to establish the optimal centrifugal force and time and to show that there was a constant relationship between the number of $D$. acuminata cells added and the amount of toxin found per filter. For the first test, $0.5 \mathrm{ml}$ of $D$. acuminata culture was added to 9 centrifugal filters, and these were centrifuged at different accelerations (ranging from 50 to $12800 \times g$ ) for $1 \mathrm{~min}$. For the second test, 4 filters with $0.5 \mathrm{ml}$ of $D$. acuminata culture were centrifuged at $800 \times g$ for 30 to $240 \mathrm{~s}$. For the third test, 5 different cell concentrations of $D$. acuminata were produced (200 to 3200 cells ml $^{-1}$ ) by diluting sub-samples of another $D$. acuminata culture with $\mathrm{f} / 2$ medium. Each of the cell concentrations was added to triplicate centrifugal filters, and the filters were centrifuged at $800 \times g$ for $1 \mathrm{~min}$. The filtrate was then removed from all Eppendorf tubes, and the tubes, including filter inserts, were stored at $-18^{\circ} \mathrm{C}$. Later, after 1 wk of storage, samples were extracted for $1 \mathrm{~h}$ using $100 \mu \mathrm{l} 100 \%$ methanol, and after centrifugation, the extract was transferred to a $2 \mathrm{ml}$ HPLC vial with a $250 \mu \mathrm{l}$ glass insert.

\section{Effects of irradiance, food availability and growth phase on toxin production}

Feeding experiments were set up in triplicate $65 \mathrm{ml}$ polystyrene flasks at 4 different irradiances $(7,15,30$ and $130 \mu \mathrm{mol}$ photons $\mathrm{m}^{-2} \mathrm{~s}^{-1}$, henceforth termed $I_{7}$ $I_{15}, I_{30}$ and $I_{130}$ respectively) to test the effects of irradiance, food availability and growth phase on the toxin production of Dinophysis acuminata. The same non-clonal culture, FR101009, was used also for this experiment. Two different $D$. acuminata stock cultures (both FR101009) were used for the experiment setup, one for the $I_{7}$ and $I_{30}$ treatments and the other for the $I_{15}$ and $I_{130}$ treatments. The stock culture used for the $I_{7}$ and $I_{30}$ treatments was starved for $\sim 1 \mathrm{mo}$ before the experiment was initiated, whereas the stock culture used for the $I_{15}$ and $I_{130}$ treatments was relatively well fed and in exponential growth. Initial concentrations were setup at $\sim 200$ D. acuminata $\mathrm{ml}^{-1}$ and 2000 Mesodinium rubrum $\mathrm{ml}^{-1}$. At subsequent samplings (every 3 to $4 \mathrm{~d}$ ), cell concentrations were adjusted to these target concentrations (after counting) by diluting with $\mathrm{f} / 2$ medium and adding $M$. rubrum culture that had been grown at, and fed with T. amphioxeia that also had been grown at the corresponding treatment irradiances. D. acuminata was grown this way for 5 to 7 samplings, corresponding to 
15 to $25 \mathrm{~d}$, and after this, cellular gross photosynthetic rates were measured, and $2\left(I_{7}\right.$ and $\left.I_{30}\right)$ of the 4 irradiance level treatments were terminated. The other $2\left(I_{15}\right.$ and $\left.I_{130}\right)$ were allowed to continue, but with no additional dilutions or food additions. The experiments were conducted in a $15^{\circ} \mathrm{C}$ temperaturecontrolled room, using the same seawater medium as for culturing. Irradiance was provided by a cool white light source providing $130 \mu \mathrm{mol}$ photons $\mathrm{m}^{-2} \mathrm{~s}^{-1}$ on a $16 \mathrm{~h}$ light:8 $\mathrm{h}$ dark cycle, and neutral density filters were applied to achieve the reduced irradiance levels.

At each sampling, $3 \mathrm{ml}$ subsamples were removed from each flask, and cells were fixed using acidic Lugol's solution in a final concentration of 1 to $2 \%$. Cell counts were performed on an Olympus CK2 inverted microscope at 40 to $200 \times$ using $1 \mathrm{ml}$ Sedgewick-Rafter sedimentation chambers. A minimum of 200 cells was counted when possible. When cell concentrations were $<200 \mathrm{ml}^{-1}$, a minimum volume of $1 \mathrm{ml}$ was inspected. Based on these microscopy cell enumerations, exponential growth rates $(\mu)$ of Dinophysis acuminata and Mesodinium rubrum were calculated from the following equation:

$$
\mu=\frac{\ln \left(\frac{N_{t}}{N_{0}}\right)}{t}
$$

where $t$ is the time (in days) between 2 consecutive samplings, and $N_{0}$ and $N_{t}$ are the cell concentrations at the beginning and at the end of this sampling interval.

On the final day of feeding, micrographs were taken of well-fed D. acuminata to document possible chloroplast acclimation. Normal light micrographs were taken using an Olympus BX50 microscope equipped with an Olympus DP71 color camera using the software Cell ${ }^{\mathrm{F}}$ (Olympus). For epifluorescence microscopy, $5 \mathrm{ml}$ subsamples were fixed with glutaraldehyde (final solution $2 \%$ ) and gently filtered onto $25 \mathrm{~mm}$ black $2 \mu \mathrm{m}$ nuclepore filters that were mounted in non-fluorescent immersion oil. Micrographs were taken with a monochrome digital camera (Soft Imaging System FViewII) mounted on an Olympus IX81 inverted microscope equipped with a spinning-disk unit (DSU) and a green filter cube (U-MWIG3 green: excitation 530 to $550 \mathrm{~nm}$; emission filter $575 \mathrm{~nm}$ ).

Cell dimensions of Dinophysis acuminata were measured on Lugol's preserved samples from the final day of feeding at 400x using an Olympus CK2 inverted microscope. Lengths and widths of 10 cells from each replicate were measured. Cell thicknesses were measured on the first 10 cells found in a position that allowed widths to be measured, and the 10 values were assigned randomly to the 10 length/ width pairs. The biovolume of $D$. acuminata was calculated as a rotational ellipsoid with an elliptic crosssectional area, and cellular carbon contents were calculated from the biovolumes following the equation from Menden-Deuer \& Lessard (2000).

Subsamples $(1 \mathrm{ml})$ were removed from each flask for photosynthesis measurements at the end of the 'well-fed' period, and for $I_{15}$ and $I_{130}$, subsamples were also collected thrice during the starved period. A total of $80 \mathrm{D}$. acuminata cells were picked from the $1 \mathrm{ml}$ subsamples and washed once in $\mathrm{f} / 2$ medium by micromanipulation using a stereoscope. A total of 40 cells were transferred to each of two $20 \mathrm{ml}$ glass scintillation vials containing $2 \mathrm{ml} \mathrm{f} / 2$ medium, and $20 \mu \mathrm{l}$ of $\mathrm{NaH}_{14} \mathrm{CO}_{3}$ stock solution (specific activity = $100 \mu \mathrm{Ci} \mathrm{ml}^{-1}$, Carbon-14 Centralen) was added. One vial was incubated for $\sim 3 \mathrm{~h}$ at treatment irradiance, while the other was kept in complete darkness (by wrapping in several layers of aluminum foil). After incubation, a $100 \mu \mathrm{l}$ sub-sample was transferred to a new vial containing $200 \mu \mathrm{l}$ phenylethylamine for determination of specific activity. The remaining $1.9 \mathrm{ml}$ were acidified with $2 \mathrm{ml} 10 \%$ glacial acetic acid in methanol and evaporated overnight at $60^{\circ} \mathrm{C}$ to remove all inorganic carbon. The residue was then re-dissolved in $2 \mathrm{ml}$ Milli-Q water. All vials were treated with $10 \mathrm{ml}$ Packard Insta-Gel Plus scintillation cocktail, and disintegrations per minute were measured using a Packard 1500 Tri-Carb liquid scintillation analyzer with automatic quench correction. The photosynthetic activity (PA, pg C cell-1 $\mathrm{h}^{-1}$ ) per cell was calculated as follows:

$$
\mathrm{PA}=\frac{\mathrm{DPM} \times[\mathrm{DIC}]}{{ }^{14} \mathrm{C}_{\text {added }} \times \mathrm{h} \times \text { cells }}
$$

where DPM is disintegrations $\mathrm{min}^{-1}$, DIC is the concentration of dissolved inorganic carbon $\left(\mathrm{pg} \mathrm{C} \mathrm{ml}^{-1}\right)$, ${ }^{14} \mathrm{C}_{\text {added }}$ is the specific activity (disintegrations $\mathrm{min}^{-1}$ $\left.\mathrm{ml}^{-1}\right), \mathrm{h}$ is the incubation time, and cells is the number of cells in the vial.

DIC concentrations were measured on $1 \mathrm{ml}$ subsamples using an ADC $225 \mathrm{Mk} 3$ infrared gas analyzer as described elsewhere (Nielsen et al. 2007). Glass vials with screw caps were used for DIC samples allowing no headspace, and the samples were analyzed within a few hours.

DSP toxins were quantified at each sampling by transferring a $0.5 \mathrm{ml}$ subsample from each flask to $0.5 \mathrm{ml}$ centrifugal filters (pore size $=0.45 \mu \mathrm{m}, \mathrm{VWR}$ ). Based on results from the centrifugal filter tests, the 
samples were centrifuged at $400 \times g$ for $2 \mathrm{~min}$. The filtrate was removed, and Eppendorf tubes with filter inserts were stored at $-18^{\circ} \mathrm{C}$ until later extraction and analysis. Samples were extracted as described for the first experiment.

\section{Additional experiments at 15 and $130 \mu \mathrm{mol}$ photons $\mathrm{m}^{-2} \mathrm{~s}^{-1}$}

An additional, similar set of experiments were conducted at 15 and $130 \mu \mathrm{mol}$ photons $\mathrm{m}^{-2} \mathrm{~s}^{-1}$ after the completion of the first set (henceforth termed $I_{15-2}$ and $I_{130-2}$ ). The setup was the same as in the previous experiments, but 4 times during the experiments, in addition to the previously described method, DSP toxins were also sampled by picking 300 Dinophysis acuminata cells under a stereoscope using glass Pasteur pipettes. The cells were washed once in $\mathrm{f} / 2$ growth medium and transferred to an Eppendorf spin filter. From there, they were centrifuged and processed like the other toxin samples. Additionally, $\mathrm{pH}$ was recorded at each sampling using a WTW $3210 \mathrm{pH}$ meter equipped with a WTW Sentix 41 combination electrode, calibrated before each use with standard NBS pH 7 and 10 buffers. The aim of these additional experiments was to establish how much of the observed toxicity was actually found intracellularly during the different growth phases.

\section{Toxin measurements}

Measurements were done on an ABI-SCIEX-4000 Q Trap (Applied Biosystems) triple quadrupole mass spectrometer equipped with a TurboSpray ${ }^{\circledR}$ interface coupled to an Agilent model 1100 LC. The LC equipment included a solvent reservoir, in-line degasser (G1379A), binary pump (G1311A), refrigerated autosampler (G1329A/G1330B) and temperaturecontrolled column oven (G1316A).

After injection of $5 \mu \mathrm{l}$ of sample, separation of lipophilic toxins was performed by reverse-phase chromatography on a C8 column $(50 \times 2 \mathrm{~mm})$ packed with $3 \mu \mathrm{m}$ Hypersil BDS $120 \AA$ (Phenomenex) and maintained at $20^{\circ} \mathrm{C}$. The flow rate was $0.2 \mathrm{ml} \mathrm{min}^{-1}$, and gradient elution was performed with 2 eluents, where eluent A was water and eluent B was acetonitrile/ water $(95: 5 \mathrm{v} / \mathrm{v})$, both containing $2.0 \mathrm{mmol} \mathrm{l}^{-1} \mathrm{ammo-}$ nium formate and $50 \mathrm{mmol} \mathrm{l}^{-1}$ formic acid. Initial conditions were 12 min column equilibration with $5 \% \mathrm{~B}$ followed by a linear gradient to $100 \% \mathrm{~B}$ within $10 \mathrm{~min}$ and isocratic elution until 15 min with $100 \%$ B. The program was then returned to the initial conditions for $18 \mathrm{~min}$ (total run time: $30 \mathrm{~min}$ ).

The chromatographic run was divided into 3 periods: (1) 0 to $8.75 \mathrm{~min}$ for domoic acid, (2) 8.75 to 11.20 min for gymnodimine and spirolides and (3) 11.20 to 18 min for OA, DTXs, PTXs, yessotoxin and azaspiracid-1 (curtain gas: 10 psi, CAD gas: medium, ion spray voltage: $5500 \mathrm{~V}$, temperature: ambient, nebulizer gas: $10 \mathrm{psi}$, auxiliary gas: off, interface heater: on, declustering potential: $50 \mathrm{~V}$, entrance potential: $10 \mathrm{~V}$, exit potential: $15 \mathrm{~V}$ ). Selected reaction monitoring experiments were carried out in positive ion mode by selecting the following transitions (precursor ion $>$ fragment ion) for period 3: specific mass to charge ratio $(\mathrm{m} / \mathrm{z}) 822>223$ (collision energy, CE: $55 \mathrm{~V}$ ) for OA and DTX-2, m/z $836>237$ (CE: 55 V) for DTX-1, m/z $946>223$ (CE: 55 V) for OA diol ester, m/z $874>213$ (CE: $55 \mathrm{~V}$ ) for pectenotoxin-12 (Miles et al. 2004b) and PTX-14, m/z $876>213$ (CE: $55 \mathrm{~V}$ ) for PTX-2, m/z $892>213$ (CE: 55 V) for PTX-1, PTX-4, PTX-8, PTX-11 and PTX-13, m/z $894>213$ (CE: 55 V) for PTX-2 seco acid, m/z $842>824$ (CE: 55 V) for azaspiracid-1 and m/z $1160>965$ (CE: $55 \mathrm{~V}$ ) for yessotoxin. Dwell times of 100 to $200 \mathrm{~ms}$ were used for each transition.

\section{Calculations and statistical analyses}

The generation time $(\tau)$ for each irradiance treatment during the well-fed period was calculated as $\tau=$ $\ln (2) / \mu$. Carbon contributions from photosynthetic activity $\left(\mathrm{C}_{\mathrm{PA}}\right)$ during the well-fed period were calculated as follows:

$$
\mathrm{C}_{\mathrm{PA}}=\frac{\mathrm{PA} \times \mathrm{h}_{\text {light }} \times \tau}{\mathrm{C}_{\text {cell }}}
$$

where $\mathrm{h}_{\text {light }}$ is the daily hours of light $(=16), \tau$ is generation time in days, and $\mathrm{C}_{\text {cell }}$ is the carbon content per Dinophysis acuminata cell.

Acclimated growth rate and PA were both fitted to treatment irradiances according to the model of Harrison \& Platt (1986) using the 'Regression Wizard' of SigmaPlot 12.0:

$$
\mathrm{PA}=P_{\max }\left(1-\mathrm{e}^{-\left(\frac{\alpha \cdot E_{\mathrm{d}}}{P_{\max }}\right)}\right)
$$

where $P_{\max }$ is the photosynthetic capacity at saturating light, $\alpha$ is the initial slope, and $E_{\mathrm{d}}$ is the downwelling irradiance (PAR).

Daily toxin production rates $\left(R_{\text {tox }}\right)$ were calculated as follows: 

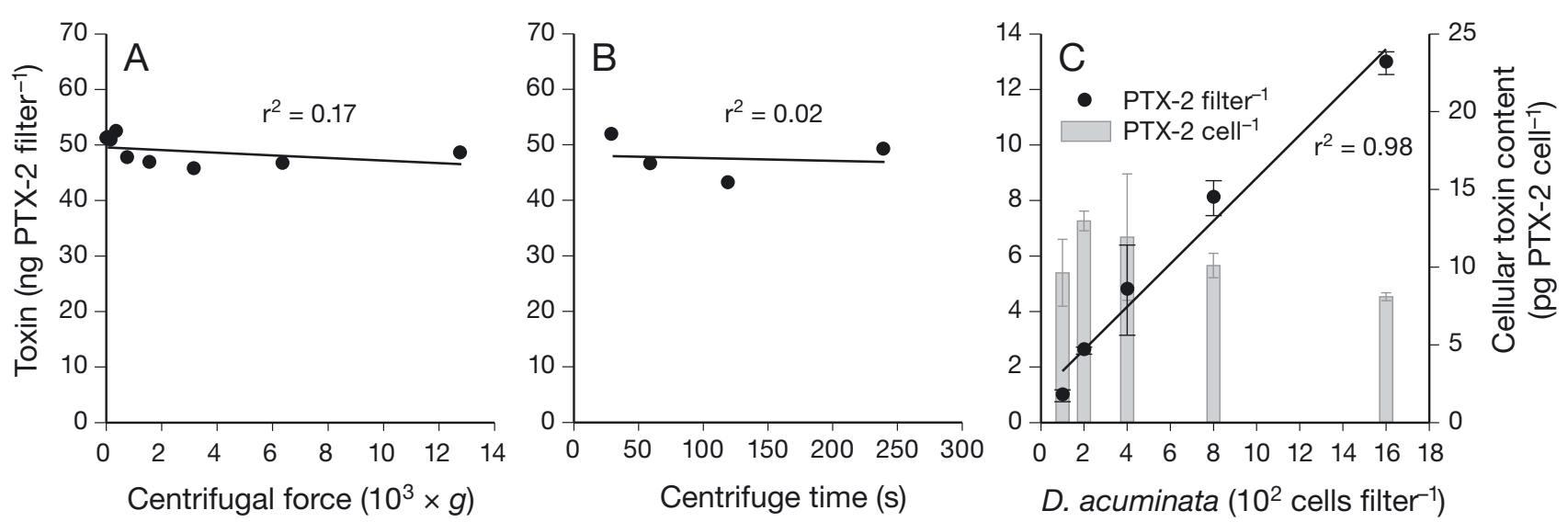

Fig. 1. Dinophysis acuminata. Initial toxin sampling tests with centrifugal filters. Pectenotoxin-2 (PTX-2) collected per filter as a function of (A) the centrifugal force applied (time $=1 \mathrm{~min}$ ), (B) centrifuge time (force $=800 \times g$ ) and (C) (dots and line) number of $D$. acuminata cells per filter $(1 \mathrm{~min}$ at $800 \times g)$ and (bars) cellular PTX-2 quotas calculated from the same data. Symbols and error bars represent mean $\pm \mathrm{SD}(\mathrm{n}=3)$

$$
R_{t o x}=\frac{T_{2}-T_{1}}{\bar{N} \times\left(t_{2}-t_{1}\right)}
$$

where $T_{1}$ and $T_{2}$ are toxin contents per $\mathrm{ml}$ of culture at 2 subsequent samplings taken on days $t_{1}$ and $t_{2}$, and $\bar{N}$ is the ln-average of the cell concentration per ml calculated as follows:

$$
\bar{N}=\frac{N_{2}-N_{1}}{\ln \left(N_{2} / N_{1}\right)}
$$

All statistical comparisons between the 4 irradiance treatments were made in SigmaStat 3.5 using 1way ANOVA with a predefined $\alpha$ of 0.05 and a Tukey test for pairwise comparisons. All results are presented as mean $\pm \mathrm{SD}$.

\section{RESULTS}

\section{DSP toxin contents of 7 Danish strains of Dinophysis acuminata}

Under the standard laboratory conditions given in the previous section, all 7 analyzed strains of $D$. acuminata contained PTX-2 in the range of 12.7 to $35.6 \mathrm{pg} \mathrm{cell}^{-1}$, whereas none of them produced OA or DTX.

\section{Toxin sampling tests}

Results from the centrifugal filter tests showed that the amount of PTX-2 retrieved per filter was independent of the centrifugal force (Fig. 1A) and centrifuge time (Fig. 1B). Also, there was a good correlation $\left(\mathrm{r}^{2}=0.98\right)$ between the number of Dinophysis acuminata cells per filter and the amount of retrieved PTX-2 (Fig. 1C). Cellular PTX-2 content was 9.6 \pm 2.2 and $8.1 \pm 0.3 \mathrm{pg}$ PTX-2 cell $^{-1}$ at 100 and $1600 \mathrm{D}$. acuminata cells per filter respectively, and there were no statistically significant differences between cellular PTX-2 contents at the different $D$. acuminata concentrations assessed $(\mathrm{p}=0.11,1$-way ANOVA, $\mathrm{n}=3$ ) (Fig. 1C).

\section{Effects of light on photosynthesis, growth and cellular toxin content and production}

Dinophysis acuminata showed positive growth under all 4 irradiance treatments (Fig. 2). During the well-fed period, D. acuminata increased between samplings from 200 to $314 \pm 36,662 \pm 69,687 \pm 305$ and $1268 \pm 242$ cells $\mathrm{ml}^{-1}$ for the 4 treatments $I_{7}, I_{15}$, $I_{30}$ and $I_{130}$ respectively. At $I_{7}, I_{15}$ and $I_{30}$, Mesodinium rubrum almost always declined in numbers between samplings due to grazing exceeding new growth (Fig. 2). At $I_{130}$, the growth of $M$. rubrum often counterbalanced the rate of grazing. For all treatments, however, cell concentrations of $M$. rubrum were $>1000 \mathrm{ml}^{-1}$ most of the time during the well-fed period, and only on a single occasion did the concentration decrease below $500 \mathrm{ml}^{-1}$ ( $I_{7}$, Day 22). After $18 \mathrm{~d}$, when dilutions and feeding were terminated, $D$. acuminata in the 2 treatments $I_{15}$ and $I_{130}$ kept growing exponentially for 8 and $4 \mathrm{~d}$, respectively, after which growth was impeded (Fig. 2B,D). On Day 26, cell concentrations of $D$. acuminata were $4817 \pm 279$ and $7333 \pm 471$ cells $\mathrm{ml}^{-1}$ in treatments $I_{15}$ and $I_{130}$, respectively. Growth continued slowly in $I_{15}$ until Day 47, at which point the cell concentration was 

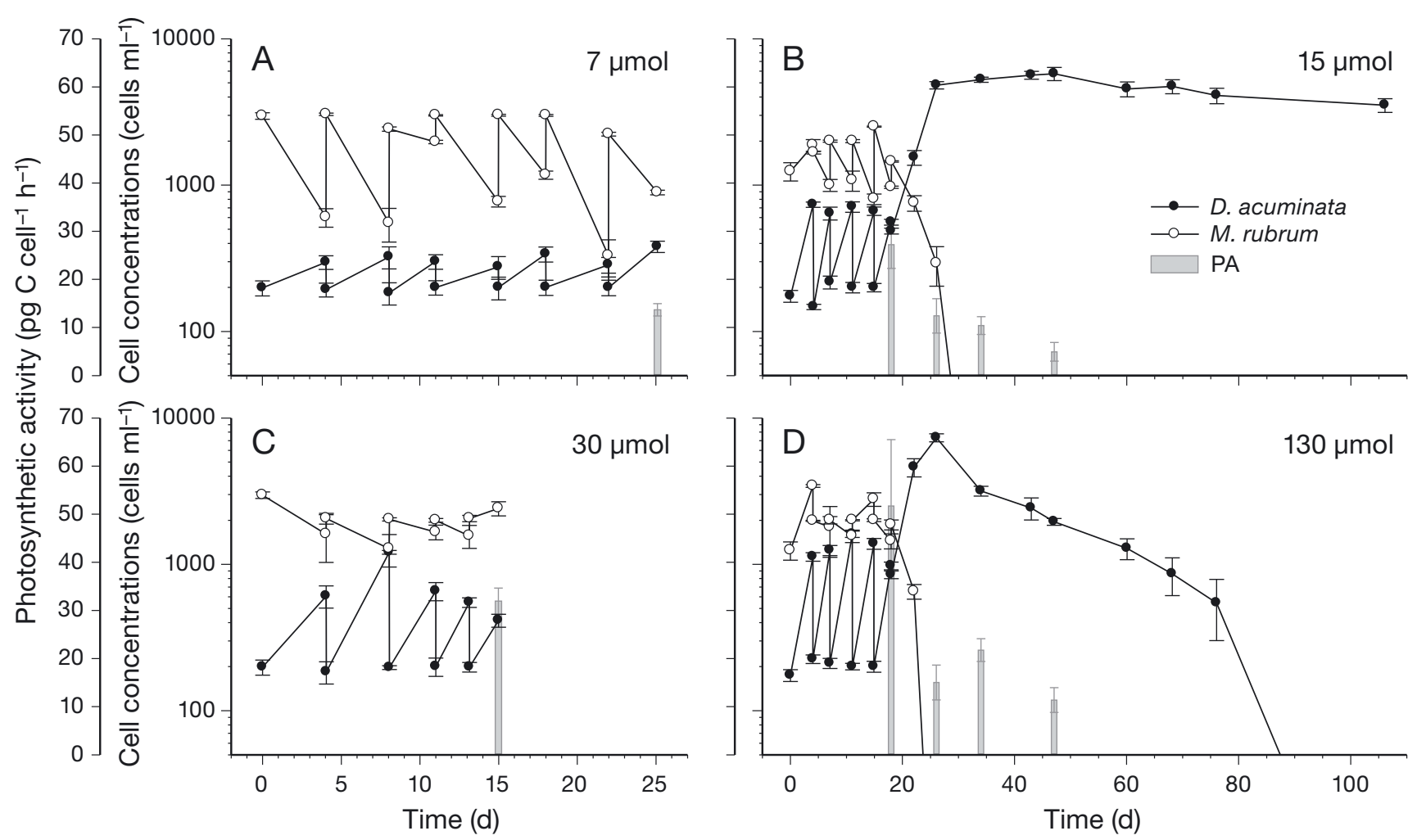

Fig. 2. Dinophysis acuminata and Mesodinium rubrum. Cell concentrations of $(\bullet)$ D. acuminata and (o) M. rubrum and (bars) rates of photosynthetic activity in the first set of experiments of the 4 treatments at 7, 15, 30 and $130 \mu \mathrm{mol}$ photons $\mathrm{m}^{-2}$ $\mathrm{s}^{-1}\left(I_{7}, I_{15}, I_{30}\right.$ and $I_{130}$ respectively). Data are mean $\pm \mathrm{SD}(\mathrm{n}=3)$

$5775 \pm 602$ cells ml$^{-1}$. After this no further growth was seen, and on Day 106 the cell concentration had declined to $3517 \pm 377$ cells $\mathrm{ml}^{-1}$. $I_{130}$, in contrast, showed net cell death immediately after the cell concentration peaked on Day 26. On Day 76, the cell

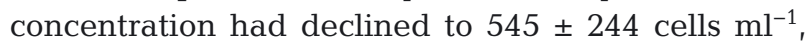
and no cells were alive on Day 106. $M$. rubrum was completely gone after 8 to 12 and 4 to $8 \mathrm{~d}$ in $I_{15}$ and $I_{130}$, respectively.

Dinophysis acuminata $\mu$-values during the well-fed period were $0.136 \pm 0.008,0.340 \pm 0.006,0.408 \pm$ 0.003 and $0.512 \pm 0.008 \mathrm{~d}^{-1}$ for the 4 irradiances $I_{7}, I_{15}$, $I_{30}$ and $I_{130}$, respectively (Fig. $3 \mathrm{~A}$ ). All of these were statistically significantly different $(\mathrm{p}<0.001,1$-way ANOVA, $n=3$ ). The well-fed period spanned 5 to 7 samplings (15 to $25 \mathrm{~d}$ ), and, given the achieved growth rates, this corresponds to 5 to 13 divisions. Based on the model of Harrison \& Platt (1986), the derived maximum $\mu$ was $0.51 \mathrm{~d}^{-1}$.

Rates of PA on the final day of the well-fed period were $13.7 \pm 1.3,27.2 \pm 4.9,31.9 \pm 2.7$ and $51.7 \pm$ $13.8 \mathrm{pg} \mathrm{C}$ cell $^{-1} \mathrm{~h}^{-1}$ in $I_{7}, I_{15}, I_{30}$ and $I_{130}$ respectively (Fig. 3B). Micrographs of Dinophysis acuminata from $I_{15}$ and $I_{130}$ showed increased amounts of chlorophyll at the low irradiance treatment, $I_{15}$, compared to the high irradiance treatment $I_{130}$ (Fig. 4). The modeled
$P_{\max }$ was $51.0 \mathrm{pg} \mathrm{C}$ cell $^{-1} \mathrm{~h}^{-1}$. Given the observed growth rates of the 4 treatments $I_{7}, I_{15}, I_{30}$ and $I_{130}$, photosynthetic carbon assimilation contributed $68 \pm$ $9,49 \pm 10,51 \pm 4$ and $61 \pm 17 \%$ of the carbon content of $D$. acuminata between each cell division. With an assumed growth efficiency of $50 \%$ for photoautotrophically derived carbon, this corresponds to $34 \pm$ $4,25 \pm 5,25 \pm 2$ and $30 \pm 9 \%$ of the required carbon for each division. After feeding was terminated on Day 18 and D. acuminata growth was impeded, rates of PA quickly decreased (Fig. 2B,D). For $I_{15}$, the rate decreased from $27.2 \pm 4.9$ to $12.4 \pm 3.6,10.4 \pm 1.9$ and $4.9 \pm 1.9 \mathrm{pg} \mathrm{C}$ cell $^{-1} \mathrm{~h}^{-1}$ on Day 18, 26, 34 and 47, respectively. For $I_{130}$, the rate decreased from $51.7 \pm$ 13.8 to $15.0 \pm 3.6,21.8 \pm 2.4$ and $11.4 \pm 2.6 \mathrm{pg} \mathrm{C} \mathrm{cell}^{-1}$ $\mathrm{h}^{-1}$ on Day 18, 26, 34 and 47, respectively. For both treatments, the first (well-fed) rate was statistically significantly higher than the subsequent (starved) value, whereas any further decreases as starvation continued were not statistically significant $(p<0.001$, 1 -way ANOVA, $\mathrm{n}=3$ ).

Cell dimensions of Dinophysis acuminata from all treatments were: length: $48 \pm 2 \mu \mathrm{m}$, width: $32 \pm 2 \mu \mathrm{m}$ and thickness: $16 \pm 2 \mu \mathrm{m}$. The calculated carbon content of $D$. acuminata in the 4 treatments $I_{7}, I_{15}, I_{30}$ and $I_{130}$ was $1654 \pm 200,1804 \pm 185,1711 \pm 117$ and 1856 

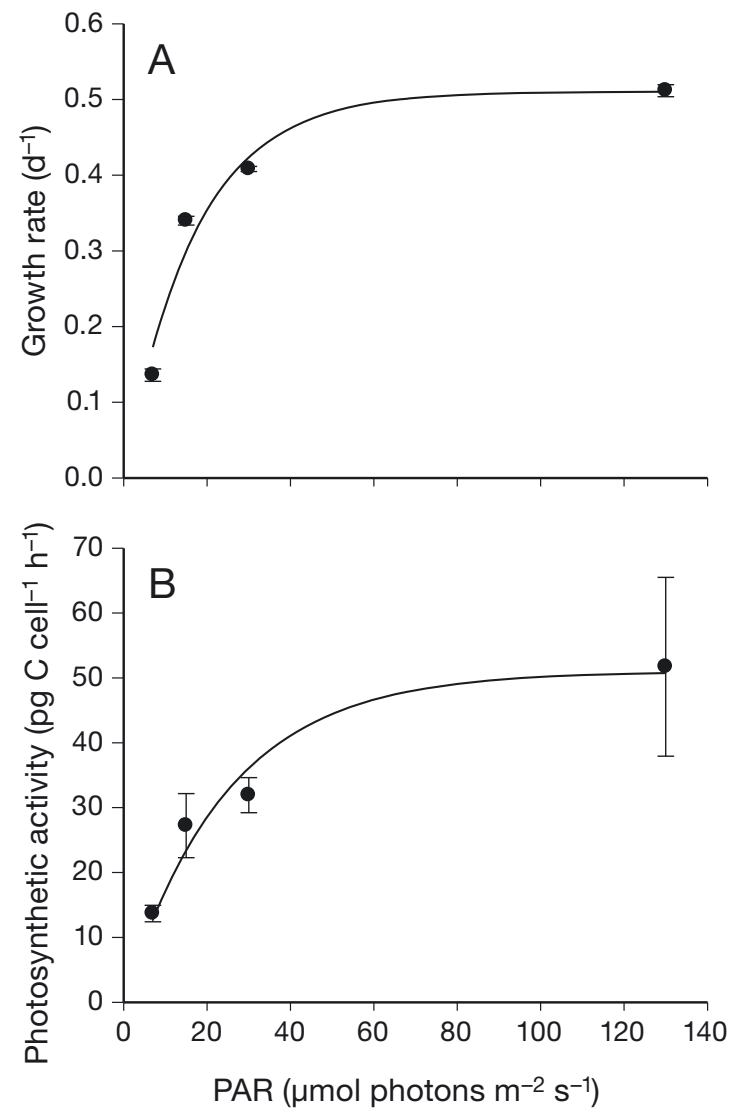

Fig. 3. Dinophysis acuminata. First set of experiments. (A) Growth rate and (B) photosynthetic activity vs. irradiance. The fitted line is after Harrison \& Platt (1986). Data are mean $\pm \mathrm{SD}(\mathrm{n}=3)$
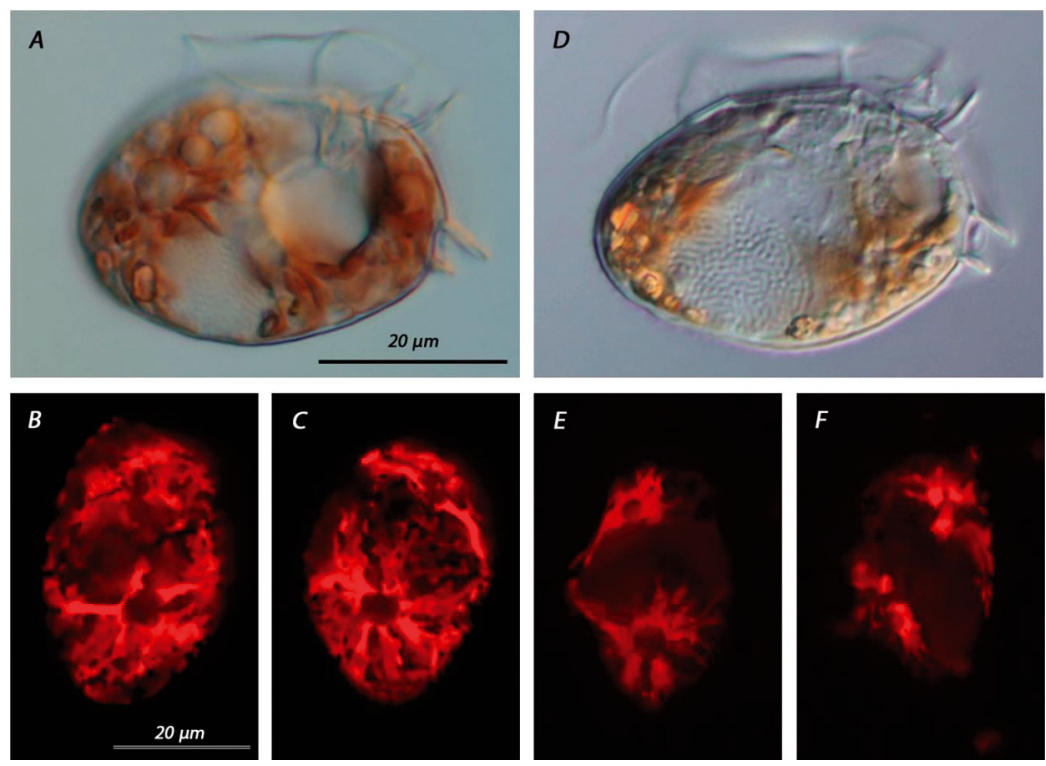

Fig. 4. Dinophysis acuminata. Representative micrographs of well-fed cells grown at (A-C) 15 and (D-F) $130 \mu \mathrm{mol}$ photons $\mathrm{m}^{-2} \mathrm{~s}^{-1}$. Epifluorescence micrographs show that $D$. acuminata had more chlorophyll when grown at $(B, C)$ $15 \mu \mathrm{mol}$ photons $\mathrm{m}^{-2} \mathrm{~s}^{-1}$ than at (E,F) $130 \mu \mathrm{mol}$ photons $\mathrm{m}^{-2} \mathrm{~s}^{-1}$ \pm 215 pg C cell ${ }^{-1}$, respectively. Carbon contents of the 4 treatments were not statistically significantly different ( $\mathrm{p}=0.56,1$-way ANOVA, $\mathrm{n}=3$ ).

PTX-2 was the primary toxin observed in all samples. Apart from this, PTX-2-sa was also observed, but always in a constant, small amount (1 to $2 \%$ ) compared to PTX-2. No OA or DTX was observed at any time. Cellular PTX-2 contents in the 4 treatments $I_{7}$, $I_{15}, I_{30}$ and $I_{130}$ were initially $29.5 \pm 3.7,8.8 \pm 2.5,29.5 \pm$ 3.3 and $8.6 \pm 2.5$ pg PTX-2 cell ${ }^{-1}$, respectively (Fig. 5). The cellular PTX-2 contents in $I_{7}$ and $I_{30}$ decreased within the first 8 to $11 \mathrm{~d}$ of feeding to an average during the remaining well-fed period of $4.4 \pm 1.2$ and 5.2 $\pm 0.9 \mathrm{pg} \mathrm{cell}{ }^{-1}$, respectively. Cellular PTX-2 contents of the $I_{15}$ and $I_{130}$ treatments were relatively stable during all of the well-fed period, averaging $7.3 \pm 2.3$ and $9.0 \pm 2.9 \mathrm{pg} \mathrm{cell}^{-1}$, respectively. For irradianceacclimated values of toxin content, only data from the last 3 samplings of the well-fed period were used, and thus well-fed, acclimated toxin contents were $4.6 \pm$ $0.3,6.2 \pm \mathrm{t} 1.1,5.1 \pm 0.5$ and $7.8 \pm 1.1 \mathrm{pg}$ PTX -2 cell $^{-1}$ in the 4 treatments $I_{7}, I_{15}, I_{30}$ and $I_{130}$, respectively (Fig. 6). The $I_{130}$ treatment had statistically significantly more PTX-2 per cell than the $I_{7}$ and $I_{15}$ treatments, whereas none of the PTX-2 contents in the other treatments differed $(\mathrm{p}=0.007,1$-way ANOVA, $\mathrm{n}=3)$. Calculated daily PTX-2 production rates during the well-fed period were highly variable, ranging from -2.7 to $3.8,0.5$ to $5.2,1.3$ to 4.4 and 1.6 to $8.0 \mathrm{pg} \mathrm{cell} \mathrm{p}^{-1}$ for $I_{7}, I_{15}, I_{30}$ and $I_{130}$, respectively. However, when averaged over the irradiance-acclimated, well-fed period for each replicate, all treatment combinations except one ( $I_{15}$ vs. $\left.I_{30}\right)$ were statistically significantly different from each other in daily PTX-2 production rates $(\mathrm{p}<0.005,1$-way ANOVA, $\mathrm{n}=3$ ). The corresponding daily rates of PTX-2 production were $0.7 \pm 0.04,2.0 \pm 0.4,2.1 \pm 0.2$ and $3.9 \pm$ $0.5 \mathrm{pg} \mathrm{cell}^{-1} \mathrm{~d}^{-1}$ (Fig. 6). After dilution and feeding ceased, the $I_{15}$ treatment showed continued positive rates of PTX-2 production for another $42 \mathrm{~d}$ (Day 60) even though cell division had stopped (Fig. 5B). Thus, toxin accumulated inside Dinophysis acuminata cells, resulting in a PTX-2 content of $24.7 \pm 1.7 \mathrm{pg}$ cell $^{-1}$ compared to the average content of $6.2 \pm 1.1 \mathrm{pg} \mathrm{cell}{ }^{-1}$ found for that irradiance during the well-fed period. For the $I_{130}$ treatment, an apparently similar increase in the 

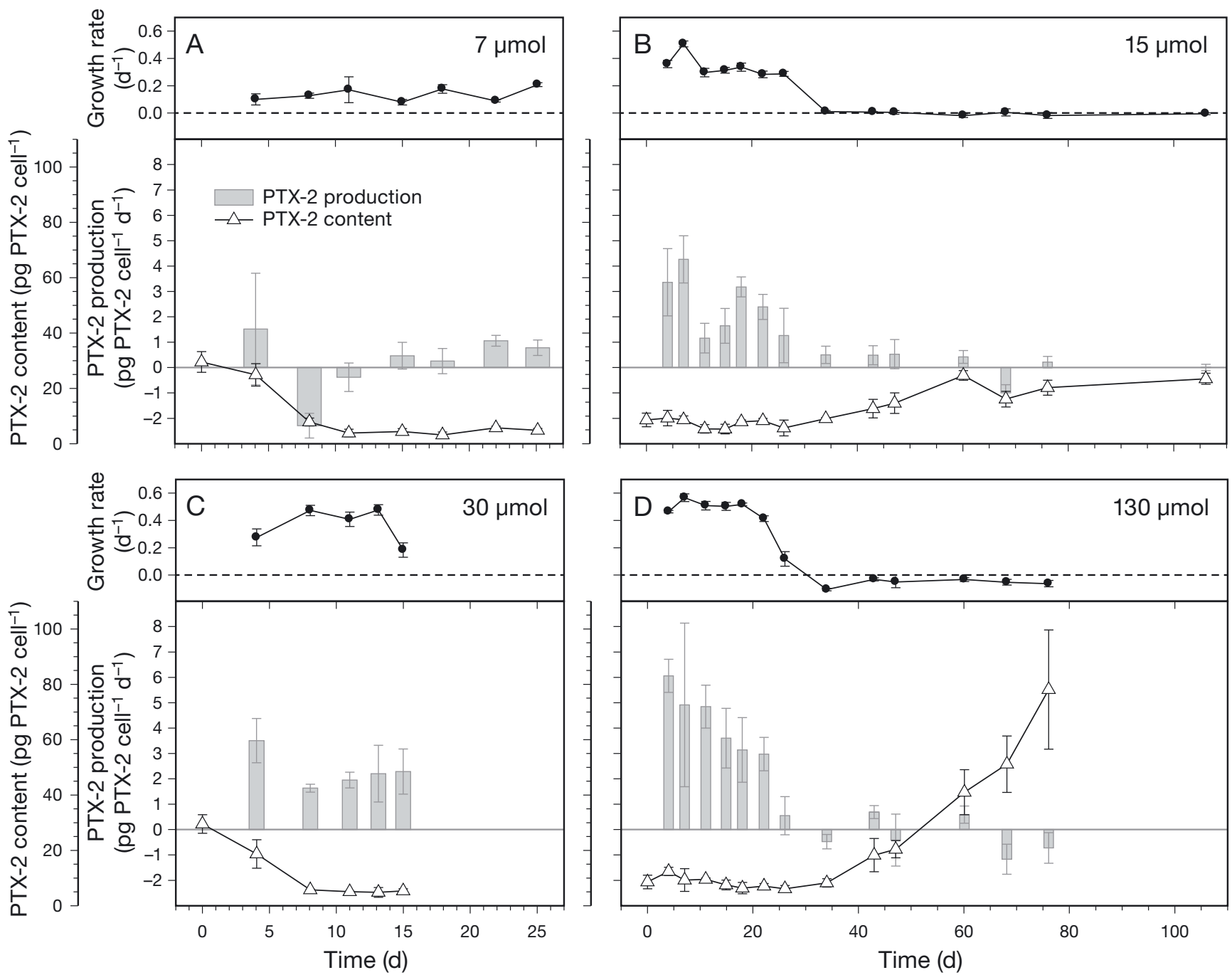

Fig. 5. Dinophysis acuminata. Toxin contents and toxin production rates in the 4 treatments during the first set of experiments (see Fig. 2). Top panels show (๑) specific growth rates of D. acuminata, whereas bottom panels show $(\Delta)$ cellular toxin contents (note the second $y$-axis) and (bars) toxin production rates. Data are mean $\pm \operatorname{SD}(n=3)$

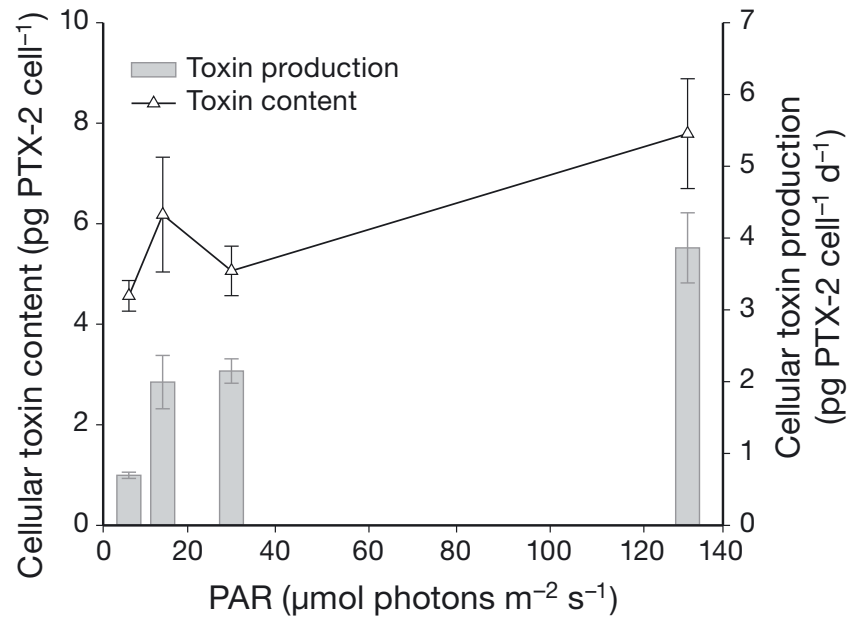

cellular toxin content was found, but it continued all the way to the end of the experiment, finally ending with a cellular toxin quota of $78.1 \pm 21.5 \mathrm{pg}$ PTX-2 cell $^{-1}$ on Day 76 (Fig. 5D).

\section{Additional experiments at 15 and $130 \mu \mathrm{mol}$ photons $\mathbf{m}^{-2} \mathrm{~s}^{-1}$}

Both additional experiments progressed similarly to their respective counterparts in the first set of experi-

Fig. 6. Dinophysis acuminata. Toxin content and production in the first set of experiments as a function of treatment irradiance. Data are mean \pm SD $(n=3)$ 


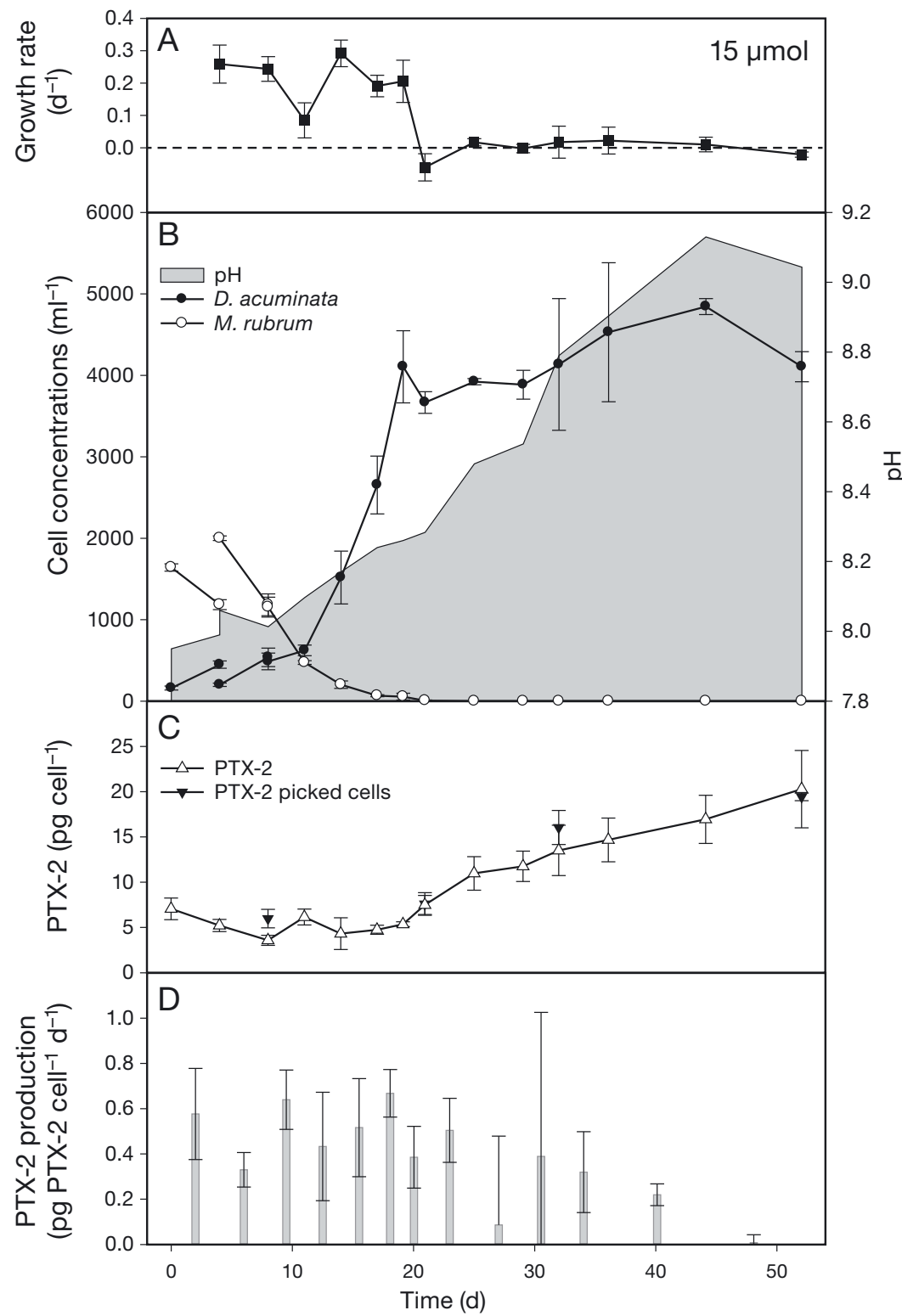

Fig. 7. Dinophysis acuminata and Mesodinium rubrum. Second set of experiments at $15 \mu \mathrm{mol}$ photons $\mathrm{m}^{-2} \mathrm{~s}^{-1}\left(I_{15-2}\right)$. (A) Specific growth rate. (B) Cell concentrations of $D$. acuminata and $M$. rubrum as well as average $\mathrm{pH}$. (C) Cellular toxin contents from $(\Delta)$ spin filter samples and $(\boldsymbol{\nabla})$ picked cells. (D) Cellular PTX-2 production rates during the $52 \mathrm{~d}$ experiment. Data are mean $\pm \mathrm{SD}(\mathrm{n}=3)$

ments (Figs. 7 \& 8). One exception was the slightly shorter acclimation period with high food availability; in the second set of experiments, food (Mesodinium rubrum) was only added the first week and was almost completely gone on Day 17 and 14 in $I_{15-2}$ and $I_{130-2,}$, respectively. After the final feeding and dilution on Day 8 , Dinophysis acuminata in $I_{15-2}$ grew exponentially until a level of 4100 cells ml ${ }^{-1}$ was reached on Day 19. From here, only very limited growth was seen until the termination of the experiment on Day 52. During the wellfed, diluted period, the $\mathrm{pH}$ in this treatment was $8.02 \pm 0.05$, but after the last dilution, it increased steadily until Day 44, when it peaked at $9.13 \pm$ 0.09 (Fig. 7B). The initial PTX-2 content was $7.06 \pm 1.20 \mathrm{pg} \mathrm{cell}^{-1}$, but this decreased slightly to an average of $4.90 \pm 0.89 \mathrm{pg} \mathrm{cell}^{-1}$ in the well-fed, exponential growth phase (Fig. 7C). During this period, the average rate of PTX-2 production was $0.53 \pm 0.19 \mathrm{pg}$ cell $^{-1} \mathrm{~d}^{-1} \quad$ (Fig. 7D). After growth ceased, PTX-2 production continued, resulting in a steady increase in the cellular PTX-2 content toward the $20.3 \pm 4.3 \mathrm{pg} \mathrm{cell}^{-1}$ found on Day 52 . On Day 8, the cellular PTX-2 content was statistically significantly higher in the sample with picked and washed $D$. acuminata cells compared to the $0.5 \mathrm{ml}$ bulk culture samples (1-way ANOVA, $p=0.02, n=3$ ), but no other differences between the 2 toxin sampling methods were found in this treatment (Fig. 7C). The $I_{130-2}$ treatment reached a higher maximum $D$. acuminata concentration of $9483 \pm$ 579 cells $\mathrm{ml}^{-1}$ on Day 20 compared to the maximum cell concentration achieved in $I_{15-2}$ (Fig. 8B). From Day 20 to Day 50, the cell concentration decreased slowly to $6080 \pm 656$ cells $\mathrm{ml}^{-1}$ and from there dropped quickly to $2894 \pm 1001$ cells ml $^{-1}$ on the final day, Day 58. In this high irradiance treatment, $\mathrm{pH}$ fluctuated more during the well-fed period, ranging from 7.88 to 8.41 , and a maximum value of 9.48 \pm 0.02 was recorded on Day 20. From here, $\mathrm{pH}$ decreased slightly until Day 58 , when a pH of $9.14 \pm 0.03$ was registered. The initial PTX-2 content of $11.6 \pm 1.9 \mathrm{pg} \mathrm{cell}^{-1}$ was somewhat higher than in the $I_{15-2}$ treatment. However, this decreased within $8 \mathrm{~d}$ to an average of $3.65 \pm 0.88 \mathrm{pg} \mathrm{cell}^{-1}$ during the acclimated, well-fed period. During the well-fed period, the PTX-2 production rate was $1.03 \pm 0.61 \mathrm{pg} \mathrm{cell}^{-1}$ $\mathrm{d}^{-1}$, and PTX-2 production continued after cell division stalled, thus increasing the cellular toxin content to $13.8 \pm 2.0 \mathrm{pg} \mathrm{cell}^{-1}$ on Day 27. On the final day, Day 58 , the cellular PTX-2 content increased even further 


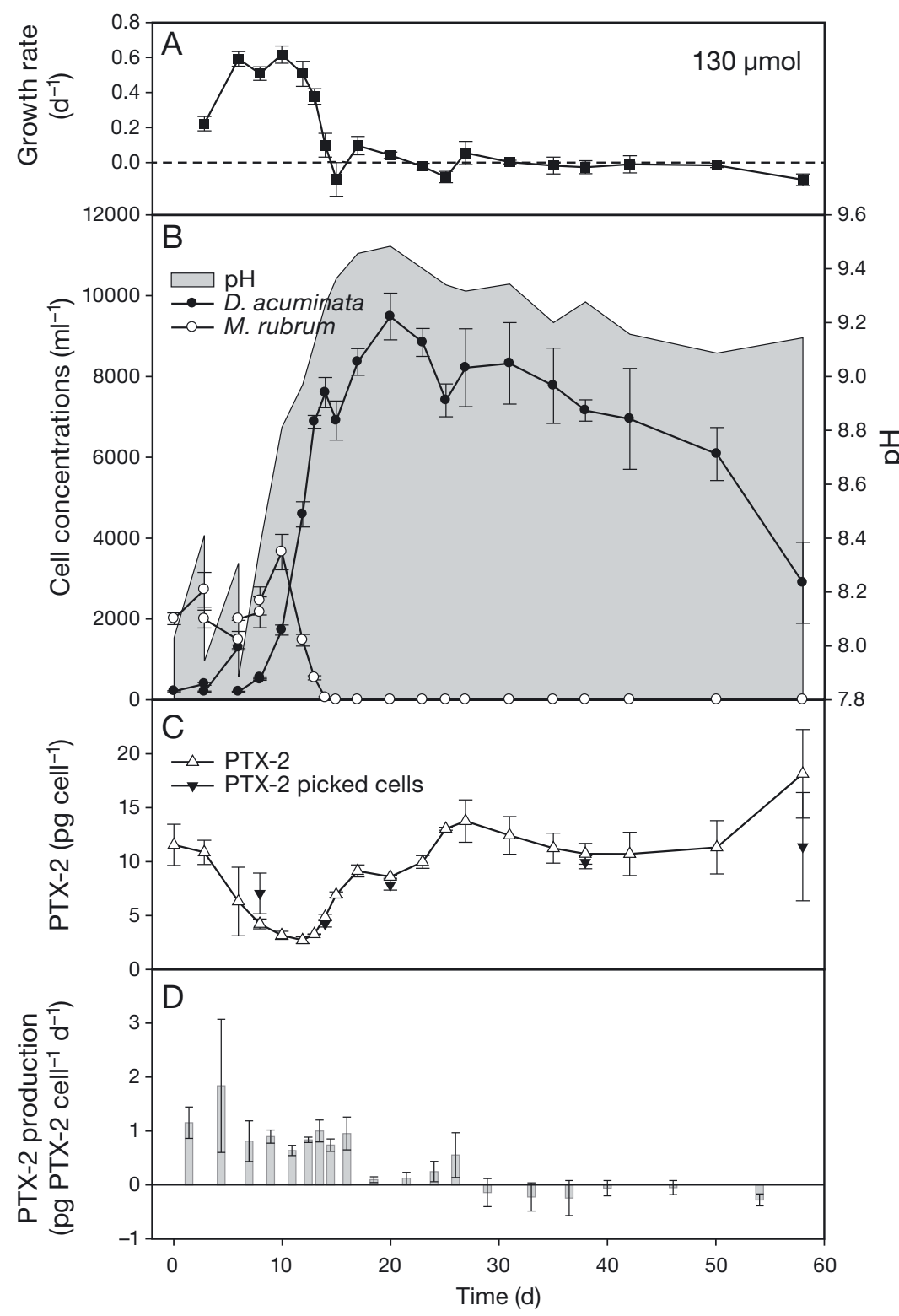

Fig. 8. Dinophysis acuminata and Mesodinium rubrum. Second set of experiments at $130 \mu \mathrm{mol}$ photons $\mathrm{m}^{-2} \mathrm{~s}^{-1}\left(\mathrm{I}_{130-2}\right)$. (A) Specific growth rate. (B) cell concentrations of $D$. acuminata and $M$. rubrum as well as average $\mathrm{pH}$. (C) Cellular toxin contents from $(\Delta)$ spin filter samples and $(\boldsymbol{\nabla})$ picked cells. (D) Cellular PTX-2 production rates during the 58 d experiment. Data are mean $\pm \mathrm{SD}(\mathrm{n}=3)$

to $18.1 \pm 4.1 \mathrm{pg}$ cell ${ }^{-1}$. On the $5 \mathrm{~d}$ when toxins were also sampled by picking and washing $D$. acuminata cells, results from the 2 methods generally mirrored each other. However, on Day 58, after the rapid cell death, the average PTX-2 content was $11.4 \pm 5.0 \mathrm{pg}$ cell $^{-1}$ in picked cells compared to $18.1 \pm 4.1 \mathrm{pg} \mathrm{cell}^{-1}$ derived from spin-filter samples. Variation was, however, too large to allow for a statistically significant difference $(p=0.15,1$-way ANOVA, $n=3)$.

\section{DISCUSSION}

\section{Effects of irradiance on growth, photosynthesis and toxin content}

The 4 treatments represented 4 different levels of light limitation in Dinophysis acuminata, from severely limited $(27 \%)$ to fully saturated $(100 \%)$ both in terms of growth and photosynthesis. Despite these clear-cut differences in both growth rate and photosynthesis, effects on cellular toxin content were very limited. First, the only toxin observed in the experiment was PTX-2 (except 1 to $2 \%$ PTX-2-sa), so changing irradiance did not trigger the production of OA, DTX or other PTX isomers. Second, while the high irradiance treatment, $I_{130}$, gave a higher PTX-2 content than the 2 lowest irradiances, the differences were $<2$ fold and thus represent only a fraction of the PTX-2 variation reported in the literature (0 to $180 \mathrm{pg}$ PTX-2 cell ${ }^{-1}$ ) (Blanco et al. 2007, Kamiyama \& Suzuki 2009). Finally, the PTX-2 content found at $130 \mu \mathrm{mol}$ photons $\mathrm{m}^{-2} \mathrm{~s}^{-1}$ in the second experiment was markedly lower than the values found for any of the irradiances in the first experiment. Although the 2 sets of experiments were separated by half a year of culturing and are thus not directly comparable, this certainly questions the robustness of the irradiance effect found in the first experiment.

Our findings support the only previous laboratory study of light effects on cellular toxin content and production in Dinophysis spp. (Tong et al. 2011). The authors concluded that irradiances from 65 to $300 \mu \mathrm{mol}$ photons $\mathrm{m}^{-2}$ $\mathrm{s}^{-1}$ had no influence on cellular toxin contents of $D$. acuminata. Also, field populations of $D$. acuta have been shown to produce toxin (OA, DTX-2 and PTX-2) below the euphotic zone, thus demonstrating that toxin production in this species is not directly coupled to photosynthetic light harvesting (Fux et al. 2010). A similar conclusion was drawn from another in situ study, based on the fact that the highest cellular toxin content (OA, DTX-2, PTX-2 and OA-D8) of D. acuta was found $8 \mathrm{~h}$ after sunset, at 
01:00 h (Pizarro et al. 2008). Thus, both field and controlled laboratory studies now indicate that toxin production in Dinophysis spp. is not directly dependent on light.

However, in the present experiment, growth and photosynthesis were equally limited by irradiance, and this could explain why irradiance did not alter toxin content much in Dinophysis acuminata. Photosynthetic carbon assimilation in each generation accounted for roughly the same proportion (49 to $68 \%$ ) of the carbon content of a $D$. acuminata cell under all irradiances. This was mediated by 2 important facts: (1) chloroplasts were clearly able to photoacclimate by increasing their cellular pigment concentration under low light (Fig. 4), and (2) ingestion rates of $D$. acuminata are known to decrease with decreasing irradiance (Kim et al. 2008). If toxin production is based on photosynthetic surplus, the 4 irradiance treatments in fact had quite similar conditions since photosynthesis constituted similar proportions of the carbon demand. We expected the contribution of the photosynthetic assimilation to vary more among the 4 treatments, but since it did not, we cannot rule out the idea that Dinophysis spp. toxin production depends on photosynthetic surplus. To further investigate this, culture conditions that increase the proportion of photosynthetically derived carbon must be employed, e.g. by reducing food availability to the point where it limits growth. This should create a scenario of slow growth but a high photosynthetic input. Further, the fact that autotrophic carbon assimilation accounted for a minimum of $25 \%$ of the carbon demand under all 4 irradiances suggests that heterotrophic carbon uptake cannot completely substitute for photosynthetically derived carbon.

\section{Effects of food availability and growth phase on photosynthesis and toxin content}

The $I_{15}$ and $I_{130}$ treatments were tracked after the well-fed period without further diluting or adding food. Within $\sim 1 \mathrm{wk}$, this resulted in a peak Dinophysis acuminata concentration and a major reduction in the PA per cell. When prey was abundant, the photosynthetic rate at $130 \mu \mathrm{mol}$ photons $\mathrm{m}^{-2} \mathrm{~s}^{-1}$ (51.7 \pm $13.8 \mathrm{pg} \mathrm{C} \mathrm{Cell}^{-1} \mathrm{~h}^{-1}$ ) was similar to the only previously published rate from a laboratory culture of $D$. acuminata (Riisgaard \& Hansen 2009). A much higher rate $\left(\leq 925 \mathrm{pg} \mathrm{cell}^{-1} \mathrm{~h}^{-1}\right)$ was found in a field study, but at high irradiances $\left(\leq 500 \mu \mathrm{mol}\right.$ photons $\left.\mathrm{m}^{-2} \mathrm{~s}^{-1}\right)$ using low-light adapted cells from deep waters (14 to $80 \mathrm{~m})$, so this rate probably reflects an artificially high value (Setala et al. 2005). The major drop in PA, found just $1 \mathrm{wk}$ after the final feeding, strongly suggests that photosynthesis in D. acuminata is tightly coupled to food uptake. The increasing $\mathrm{pH}$ found at this stage of the experiments could potentially also have caused the photosynthetic decrease, but a similar decrease found in a pH-controlled experiment with the same species suggests that this was not the case (Riisgaard \& Hansen 2009). Also, one should note that although $\mathrm{pH}$ was high in the experimental flasks, photosynthesis measurements were done in fresh medium, where $\mathrm{pH}$ would have been close to 8.0. The idea that photosynthesis in Dinophysis spp. depends on food uptake aligns well with several recent publications that all argue that these species rely on kleptoplastids, obtained from their ciliate prey, for PA. (Janson \& Graneli 2003, Minnhagen \& Janson 2006, Wisecaver \& Hackett 2010, Kim et al. 2012). However, little is known about the prevalence and dynamics of this kleptoplasty.

The cellular PTX-2 quota increased in the present experiments when food was depleted and growth stopped. In $I_{15}$ and $I_{15-2}$ as well as in the first half of $I_{130-2}$ (Days 12 to 17 ), the increase was a result of accumulation of PTX-2 in non-dividing cells, i.e. the PTX-2 content per volume of culture increased. This is very much in line with the conclusion from an earlier laboratory study with the same Dinophysis species (Tong et al. 2011). It is also in concordance with field observations from Galician waters, reporting higher toxin quotas in a senescent population of $D$. acuta compared to an exponentially growing one (Pizarro et al. 2008, Pizarro et al. 2009). The effect of growth phase was also evident at the beginning of the present experiment. Here, there was a clear-cut difference between the $I_{7}$ and $I_{30}$ treatments on one hand and the $I_{15}$ and $I_{130}$ treatments on the other hand. This difference was almost certainly caused by the fact that the treatments were set up in pairs, with the $I_{7}$ and $I_{30}$ treatments originating from one (starved) stock culture and the $I_{15}$ and $I_{130}$ treatments originating from another (well-fed) culture. Thus, it is now evident that toxin production continues at least for some weeks after growth has ceased. The fact that toxin was produced in the absence of prey demonstrates thoroughly that toxin production in $D$. acuminata does not rely directly upon food uptake in the short run (Tong et al. 2011, present study).

In $I_{130}$ and in the second half of $I_{130-2}$ (Days 17 to 27 and 50 to 58), the increases in the cellular content of PTX-2 were not caused by additional toxin production but rather by cell death and a slow rate of breakdown of the residual toxin. This resulted in an 
increasing ratio between PTX-2 and the number of viable Dinophysis acuminata cells. That implies, though, that residual toxin from dead cells binds to objects (organic matter) larger than the pore size of the spin filters $(0.45 \mu \mathrm{m})$, since free $(<0.45 \mu \mathrm{m})$ toxin was not included in our samples. If toxin leaks from D. acuminata and binds to particles, cellular toxin quotas could potentially have been overestimated during the first experiment. In the second experiment, however, the toxin contents from picked cells closely resembled those obtained from spin filter samples, indicating that this was not the case. Instead, D. acuminata cells accounted for all of the PTX-2 found at all times in the second experiment, except perhaps on the final day of the $I_{130-2}$ treatment. We assume this was not the case in $I_{130}$, where cell death was more pronounced, and the PTX-2 quota increased by a factor of 10 towards the final day of the experiment. Here, much of the toxin probably originated from dead cells instead. A slow rate of decomposition and a tendency of toxins to stick to cell debris could explain the sometimes weak coupling between Dinophysis spp. densities and toxin contents from net hauls (Pizarro et al. 2009).

\section{Conclusions and perspectives}

Cellular toxin contents varied only slightly as a function of irradiance despite the marked effects on growth rates and photosynthetic activities. Toxin production clearly decreased when food was depleted and growth stopped, but some toxin was still produced long after the last prey cells were gone, indicating that toxin production is not coupled directly to food uptake. In other words, PTX-2 is not a breakdown product directly derived from ingested food. Instead, growth phase and genetic differences between populations seem to be the cause of intraspecific differences in toxin contents within species of Dinophysis. We also showed that Dinophysis acuminata is able to photoacclimate despite the kleptoplastid nature of its chloroplasts, and that this, combined with reduced food uptake at low light, causes photosynthetic carbon assimilation to comprise a relatively stable proportion of the carbon demand of D. acuminata.

Acknowledgements. We thank W. Drebing for technical assistance with toxin measurements. We also thank 3 anonymous reviewers for their positive contributions to the manuscript. The work was funded by project no. 2101-07-0084 from the Danish Council for Strategic Research for P.J.H.

\section{LITERATURE CITED}

Blanco J, Alvarez G, Uribe E (2007) Identification of pectenotoxins in plankton, filter feeders, and isolated cells of a Dinophysis acuminata with an atypical toxin profile, from Chile. Toxicon 49:710-716

European Council (2004) Regulation (EC) No 853/2004 of the European Parliament and of the Council of 29 April 2004 laying down specific hygiene rules for food of animal origin. Off J Eur Commun 139:55-205

Fux E, Gonzalez-Gil S, Lunven M, Gentien P, Hess P (2010) Production of diarrhetic shellfish poisoning toxins and pectenotoxins at depths within and below the euphotic zone. Toxicon 56:1487-1496

$>$ Fux E, Smith JL, Tong MM, Guzman L, Anderson DM (2011) Toxin profiles of five geographical isolates of Dinophysis spp. from North and South America. Toxicon 57:275-287

Guillard RR, Ryther JH (1962) Studies of marine planktonic diatoms: 1. Cyclotella nana Hustedt, and Detonula confervacea (Cleve) Gran. Can J Microbiol 8:229-239

Hackett JD, Tong MM, Kulis DM, Fux E, Hess P, Bire R, Anderson DM (2009) DSP toxin production de novo in cultures of Dinophysis acuminata (Dinophyceae) from North America. Harmful Algae 8:873-879

> Hallegraeff GM, Lucas IAN (1988) The marine dinoflagellate genus Dinophysis (Dinophyceae): photosynthetic, neritic and non-photosynthetic, oceanic species. Phycologia 27:25-42

Hansen PJ, Moldrup M, Tarangkoon W, Garcia-Cuetos L, Moestrup O (2012) Direct evidence for symbiont sequestration in the marine red tide ciliate Mesodinium rubrum. Aquat Microb Ecol 66:63-75

> Harrison WG, Platt T (1986) Photosynthesis-irradiance relationships in polar and temperate phytoplankton populations. Polar Biol 5:153-164

Janson S, Graneli E (2003) Genetic analysis of the psbA gene from single cells indicates a cryptomonad origin of the plastid in Dinophysis (Dinophyceae). Phycologia 42: 473-477

Jørgensen K, Andersen P (2007) Relation between the concentration of Dinophysis acuminata and diarrheic shellfish poisoning toxins in blue mussels (Mytilus edulis) during a toxic episode in the Limfjord (Denmark), 2006. J Shellfish Res 26:1081-1087

> Kamiyama T, Suzuki T (2009) Production of dinophysistoxin-1 and pectenotoxin-2 by a culture of Dinophysis acuminata (Dinophyceae). Harmful Algae 8:312-317

> Kamiyama T, Nagai S, Suzuki T, Miyamura K (2010) Effect of temperature on production of okadaic acid, dinophysistoxin-1, and pectenotoxin-2 by Dinophysis acuminata in culture experiments. Aquat Microb Ecol 60:193-202

Kim S, Kang YG, Kim HS, Yih W, Coats DW, Park MG (2008) Growth and grazing responses of the mixotrophic dinoflagellate Dinophysis acuminata as functions of light intensity and prey concentration. Aquat Microb Ecol 51: 301-310

Kim JH, Lee KJ, Suzuki T, Kang YS, Kim PH, Song KC, Lee TS (2010) Seasonal variability of lipophilic shellfish toxins in bivalves and waters, and abundance of Dinophysis spp. in Jinhae Bay, Korea. J Shellfish Res 29:1061-1067

> Kim M, Nam SW, Shin W, Coats DW, Park MG (2012) Dinophysis caudata (Dinophyceae) sequesters and retains plastids from the mixotrophic ciliate prey Mesodinium rubrum. J Phycol 48:569-579

> Lindahl O, Lundve B, Johansen M (2007) Toxicity of Dino- 
physis spp. in relation to population density and environmental conditions on the Swedish west coast. Harmful Algae 6:218-231

MacKenzie L, Beuzenberg V, Holland P, McNabb P, Suzuki T, Selwood A (2005) Pectenotoxin and okadaic acidbased toxin profiles in Dinophysis acuta and Dinophysis acuminata from New Zealand. Harmful Algae 4:75-85

Menden-Deuer S, Lessard EJ (2000) Carbon to volume relationships for dinoflagellates, diatoms, and other protist plankton. Limnol Oceanogr 45:569-579

Miles CO, Wilkins AL, Munday R, Dines MH and others (2004a) Isolation of pectenotoxin-2 from Dinophysis acuta and its conversion to pectenotoxin-2 seco acid, and preliminary assessment of their acute toxicities. Toxicon 43:1-9

Miles CO, Wilkins AL, Samdal IA, Sandvik M and others (2004b) A novel pectenotoxin, PTX-12, in Dinophysis spp. and shellfish from Norway. Chem Res Toxicol 17: 1423-1433

Miles CO, Wilkins AL, Hawkes AD, Jensen DJ and others (2006) Isolation and identification of pectenotoxins-13 and -14 from Dinophysis acuta in New Zealand. Toxicon 48:152-159

Minnhagen S, Janson S (2006) Genetic analyses of Dinophysis spp. support kleptoplastidy. FEMS Microbiol Ecol 57: 47-54

Murakami Y, Oshima Y, Yasumoto T (1982) Identification of okadaic acid as a toxic component of a marine dinoflagellate Prorocentrum lima. Bull Jpn Soc Sci Fish 48:69-72

Nagai S, Suzuki T, Nishikawa T, Kamiyama T (2011) Differences in the production and excretion kinetics of okadaic acid, dinophysistoxin-1, and pectenotoxin-2 between cultures of Dinophysis acuminata and Dinophysis fortii isolated from Western Japan. J Phycol 47:1326-1337

Nielsen LT, Lundholm N, Hansen PJ (2007) Does irradiance influence the tolerance of marine phytoplankton to high $\mathrm{pH}$ ? Mar Biol Res 3:446-453

Pan Y, Cembella AD, Quilliam MA (1999) Cell cycle and toxin production in the benthic dinoflagellate Prorocentrum lima. Mar Biol 134:541-549

Park MG, Kim S, Kim HS, Myung G, Kang YG, Yih W (2006) First successful culture of the marine dinoflagellate Dinophysis acuminata. Aquat Microb Ecol 45:101-106

Editorial responsibility: Graham Savidge, Portaferry, UK
Pizarro G, Escalera L, Gonzalez-Gil S, Franco JM, Reguera B (2008) Growth, behaviour and cell toxin quota of Dinophysis acuta during a daily cycle. Mar Ecol Prog Ser 353: 89-105

- Pizarro G, Paz B, Gonzalez-Gil S, Franco JM, Reguera B (2009) Seasonal variability of lipophilic toxins during a Dinophysis acuta bloom in Western Iberia: differences between picked cells and plankton concentrates. Harmful Algae 8:926-937

> Reguera B, Velo-Suarez L, Raine R, Park MG (2012) Harmful Dinophysis species: a review. Harmful Algae 14: 87-106

Riisgaard K, Hansen PJ (2009) Role of food uptake for photosynthesis, growth and survival of the mixotrophic dinoflagellate Dinophysis acuminata. Mar Ecol Prog Ser 381: 51-62

Setala O, Autio R, Kuosa H, Rintala J, Ylostalo P (2005) Survival and photosynthetic activity of different Dinophysis acuminata populations in the northern Baltic Sea. Harmful Algae 4:337-350

Suganuma M, Fujiki H, Suguri H, Yoshizawa S and others (1988) Okadaic acid: an additional non-phorbol-12tetradecanoate-13-acetate-type tumor promoter. Proc Natl Acad Sci USA 85:1768-1771

> Tong MM, Kulis DM, Fux E, Smith JL, Hess P, Zhou QX, Anderson DM (2011) The effects of growth phase and light intensity on toxin production by Dinophysis acuminata from the northeastern United States. Harmful Algae $10: 254-264$

> Vale P, Sampayo MAD (2000) Dinophysistoxin-2: a rare diarrhoeic toxin associated with Dinophysis acuta. Toxicon 38:1599-1606

> Wisecaver JH, Hackett JD (2010) Transcriptome analysis reveals nuclear-encoded proteins for the maintenance of temporary plastids in the dinoflagellate Dinophysis acuminata. BMC Genomics 11:366

> Yasumoto T, Oshima Y, Yamaguchi M (1978) Occurrence of a new type of shellfish poisoning in Tohoku District. Bull Jpn Soc Sci Fish 44:1249-1255

> Yasumoto T, Oshima Y, Sugawara W, Fukuyo Y, Oguri H, Igarashi T, Fujita N (1980) Identification of Dinophysis fortii as the causative organism of diarrhetic shellfish poisoning. Bull Jpn Soc Sci Fish 46:1405-1411

Submitted: June 20, 2012; Accepted: August 28, 2012 Proofs received from author(s): December 3, 2012 